\title{
There is plagiarism ....and then there is plagiarism: academic misconduct and admission to legal practice
}

\section{Introduction}

Academic misconduct is a problem shared by the global legal profession (Thomas et al., 2017; Hansen \& Anderson, 2015; Freckleton, 2010; Corbin \& Carter, 2007; Bermingham et al., 2010;). It is also a growing problem (James \& Mahmud, 2014; Lindsay 2011; Corbin \& Carter, 2007; Hughes \& McCabe, 2006) which impacts law schools, law students and the practitioner. For the law school plagiarism raises questions concerning academic integrity and consequential reputation loss. For the law student plagiarism may lead to exclusion from study and may impact upon admission to practice. For the practitioner, academic misconduct may impact '...from law student to practitioner, and even to the bench' (Thomas et al., 2017: 3).

This article addresses the problem of plagiarism in law schools as a failure of regulation and regulatory policy. While acknowledging the individual responsibility each law student has to act with integrity and abide by university policy, it identifies significant variation across Australian law school plagiarism policies. The study reported in this article confirms that the current framework of plagiarism rules and policies across the 35 Australian universities offering law degrees ${ }^{i i}$ is one of disparate standards, ad hoc treatment of students and differential implementation of plagiarism policies. Similar findings have been made internationally (Bermingham et al., 2010). This wide variation in plagiarism policies means that that similar acts of plagiarism at different Australian universities may produce varied prospects for admission to practice law. The suggestion is made that a more effective regulatory oversight mechanism through the legal professional admission boards is required to promote standards of integrity and gate keep the legal profession against plagiarists. iii As a result of this study further research is required into whether, at the admission stage, it is possible and desirable to promote a nationwide uniform approach to disclosure of 'suitability' matters concerning plagiarism (see also Haller \& Bartlett, 2016).

This article confirms the ongoing need for change in the approach law schools take to plagiarism and it concludes that this regulatory gap can most likely be more effectively addressed by the legal profession admission boards. Ten years ago divergence in law school plagiarism policy iv was identified as a "current issue" of concern by the Law Admissions Consultative Committee (LACC). The LACC consists of representatives of the Law Admitting Authority in each Australian jurisdiction, the Committee of Australian Law Deans, the Australasian Professional Legal Education Council and the Law Council of Australia. This 
article confirms that over a decade later this problem remains 'current' across all law schools. Indeed it may be that the elusive definition of plagiarism is the most significant barrier to a uniform regulatory solution being offered by law schools. Here it is suggested that this regulatory failure may be addressed by the legal profession itself; a consistent and normative definition of the plagiarism may be enforced at the level of entry to legal practice. This can be achieved through state and territory legal admission boards because admission to practise as a lawyer through the Supreme Court of the State or Territory in all nine Australian jurisdictions is by application to the relevant professional admission authority, and not as of right. The role of the admission board in assessing applicants is key. One aim of this article is to draw to the attention of legal professional admission bodies the possibility of a calibrated regulatory response to individual university allegations/determinations of plagiarism.

The article is divided into three parts. Part one reviews the context for this study, analysing the rules and processes for admission to practice law. Part two sets out the methodology and key findings of the research. Part three analyses the implications of the study findings and calls for further research, particularly into admission board policies and practices around plagiarism.

\section{The significance of plagiarism with respect to the study and practise of law across Australian jurisdictions}

The term 'plagiarism' is open to different interpretations. It is a 'difficult, if not impossible, concept to define' (Price, 2002: 17). Yet university policies nonetheless stipulate what constitutes plagiarism apparently eliminating the problem of the absence of universal definition (Gullifer \& Tyson, 2014). Internationally academic institutions apply their own definition of plagiarism and enforce it through disciplinary processes. In some instances departments within universities may also apply their own definition (Tennant \& Duggan, 2008). However while the frameworks of rules applied by individual institutions to combat plagiarism seek to be equitable (Park, 2004: 298), differences in application arise within institutions. Factors such as stage of degree; whether the student is undergraduate or postgraduate or local or international (Bretag et al., 2014); or whether the plagiarism is intentional or unintentional may result in differential application of rules (Stuhmcke et al., 2016). For example unintentional plagiarism brought about through lack of competency in academic writing or lack of knowledge about what constitutes plagiarism may be treated more leniently than intentional plagiarism such as contract cheating brought about through convenience; the high cost of studying; and pressure to score high grades (Batane, 2010). Plagiarism therefore exists on a spectrum with motivations ranging from carelessness (such as not understanding citation styles and referencing norms), to desperation (out of 
opportunity or split decision making in desperation) through to calculated offences (premeditated and brought about through entitlement) (Hansen \& Anderson, 2014-15: 424).

This internal variation in application of what should be a common definition of plagiarism within a university is compounded by differences across the university sector. ${ }^{v}$ While plagiarism is generally accepted to be the use of the words or ideas of another without appropriate acknowledgment (Bretag, 2013), universities adopt not only their own definition of plagiarism (Voelker et al., 2012), but they also employ different strategies to reduce plagiarism. Strategies range from teaching students about integrity (Bretag, 2013; Devlin, 2006; Park, 2003) and what constitutes ethical academic writing, to raising awareness about the dangers of plagiarism and taking disciplinary action against plagiarists (Devlin, 2006). Importantly, institutional approaches will influence student attitudes towards cheating and plagiarism (King et al., 2009). This means that the student experience of studying the same course, such as law, at different universities will differ with respect to both plagiarism rules and prevention strategies.

For law students who plagiarise, these institutional differences may impact their future career. Law students are future members of a profession for whom the public holds high expectations of integrity and ethical behaviour. Academic integrity encompasses high level behavioural values including honesty, transparency, trust, autonomy, fairness and responsibility. Even though there is no empirical evidence of a correlation between academic misconduct and conduct as a professional (Thomas et al., 2017), plagiarism may be relevant to assessing a person's character and fitness because 'it ostensibly involves an element of dishonesty, stemming from a misappropriation of another's work' (Dal Pont, 2011: 38).

\section{Entry to the legal profession and law school plagiarism}

Every Australian jurisdiction has similar three-fold admission requirements which must be met before an individual may practise law. The first two requirements relate to the academic and professional qualifications of the applicant; that is the completion of an approved course of academic study and a practical legal training program. The third requirement relates to the applicant's suitability to practise law. In all jurisdictions the relevant legislation requires the admitting authority to consider whether the applicant is 'a fit and proper person' for admission to the legal profession. ${ }^{\text {vi }}$ According to Pagone $J$ in Frugtniet $v$ Board of Examiners [2002] VSC 140, being a 'fit and proper person' in this context means:

[t]he applicant must have the personal qualities of character which are necessary to discharge the important and grave responsibilities of being a barrister and solicitor. ... The entire administration of justice in any community which is governed by law depends on the honest working of legal practitioners who can be relied upon to meet high standards of honesty and ethical behaviour... The level and extent of trust placed in what legal practitioners say or do is necessarily high and the need for honesty is self-evident and essential. 
Each Supreme Court retains the ultimate discretion to determine whether an applicant has both the necessary qualifications for admission and is a fit and proper person to be admitted (Wyburn, 2008: 317; see also Wyburn, 2009). It is incumbent on an applicant to disclose any matter that might be relevant to the admitting authority's assessment as to whether that applicant is a fit and proper person for the purposes of legal practice. Such matters include acts of plagiarism. The introduction of the 2015 Uniform Law across two of the most populous Australian states New South Wales (NSW) and Victoria (almost three quarters of Australia's lawyers), has not altered this requirement. ${ }^{\text {vii }}$

The eight Australian admission authorities are circumspect about admitting plagiarists due to the perceived link between plagiarism and dishonesty and the potential for future unethical conduct - emphasizing the importance of lawyers as ethical beings, particularly in a contemporary landscape that views lawyers as 'unethical tricksters' (Thomas et al., 2017). The link between academic misconduct and being of good character as a legal practitioner was reinforced in Re AJG [2004] QCA 88. This decision concerned a one-off incident of plagiarism. The Court noted that:

Legal practitioners must exhibit a degree of integrity which engenders in the Court and in clients unquestioning confidence in the completely honest discharge of their professional commitments. Cheating in the academic course which leads to the qualification central to practice and at a time so close to the application for admission must preclude our presently being satisfied of this applicant's fitness.

Apart from such judicial observations which link poor moral character to academic misconduct at university there is no publicly available reports by the admission boards on the number of applications refused or the reasons for approving or denying admission.

Where graduates have appealed decisions by admission boards preventing them from practising on the basis of plagiarism, the case law reveals the importance of honesty in their applications for admission. In cases where plagiarism is not disclosed to the admission body it is likely that the student will be found to not be a 'fit and proper' to practise; in cases where it is disclosed, the student may also be found to not be a 'fit and proper' to practise if their 'insight' into, and response to, their actions do not satisfy the admission authority that the applicant is currently a 'fit and proper' person (Re Liveri [2006] QCA 152; In the matter of an application by Joy Onyeledo [2015] NTSC 60. See also Haller \& Bartlett, 2016).

A particular focus of judicial analysis is intent (Thomas et al., 2017). As noted earlier, plagiarism can be categorised as intentional or unintentional. Intentional plagiarism entails committing plagiarism with full knowledge of what constitutes plagiarism and how it can be prevented whereas unintentional plagiarism is committed inadvertently due to lack of knowledge and skills to avoid it. The courts have also demonstrated that they are not only concerned with intent in terms of the act of plagiarism but are also centrally concerned with how the applicant represents that act to the admission board. In the Matter of OG, a Lawyer 
[2007] VSC 520 the Court 'separated' the act of plagiarism from a reckless or deliberate misrepresentation of the nature of the plagiarism upon admission. The Court held that the applicant, OG, in his letter of disclosure to the admitting Board, 'deliberately or recklessly' misrepresented to the Board the circumstances in which he received zero for an assignment at university. The focus on 'how' the applicant acknowledges past acts of plagiarism is further emphasised in Re Liveri [2006] QCA 152, [21]:

\footnotetext{
The findings against the respondent involve serious plagiarism, committed more than once. At relevant times, she was a person of mature years - 25 and 27 years old. Her unwillingness, subsequently, to acknowledge that misconduct, establishes a lack of genuine insight into its gravity and significance: for present purposes, where the Court is concerned with fitness to practice, that aspect is at least as significant as the academic dishonesty itself. It could not presently be concluded that the applicant is fit for admission as a legal practitioner.
}

Academic misconduct and the intent to deceive that it demonstrates will be reinforced by an absence of integrity or the absence of willingness to comprehend the esteem with which values such as truthfulness and respect are held by the legal profession.

The concern revealed in the case law over university plagiarism is shared across the national legal profession. LACC, whose main role is to forge consensus around admission requirements for the profession asked the Victorian Board of Examiners and the Association of Administrators of Law Admitting Authorities (AALAA) to assist it to 'develop a Statement about Academic Misconduct, with a view to Admitting Authorities adopting it for promulgation to law schools, Universities and prospective applicants for admission to the legal profession'. viii In 2013 LACC adopted the Disclosure Guidelines for Applicants to the Legal Profession that are now disseminated to all law schools. The LACC guidelines emphasise to applicants that it 'would be wise to disclose' academic misconduct 'whether or not a formal finding was made or a record of the incident retained by the relevant organisation'. The Guidelines also adopt an expansive understanding of 'academic misconduct':

Academic misconduct includes, but is not limited to, plagiarism, impermissible collusion, cheating and any other inappropriate conduct, whereby you have sought to obtain an academic advantage either for yourself or for some other person

The LACC disclosure guidelines have been adopted in Queensland, Western Australia, Northern Territory, NSW and Victoria. Applicants for admission in these jurisdictions are also required to make a declaration that they have read the disclosure guidelines and either do or do not have matters to declare. According to legislation in the ACT and Tasmania, applicants are required to address the list of specific 'suitability matters' set out the in the relevant legislation (Legal Profession Act 2006 (ACT) s 11; Legal Profession Act 2007 (Tas) s 9). These lists do not specifically refer to academic misconduct but do include matters that go to whether the applicant is 'currently of good fame and character'. Prospective applicants in Tasmania are also advised that matters relevant to the duty of disclosure 
include whether 'the applicant is, or has been, the subject of disciplinary action, however described, arising out of conduct in attaining academic qualifications or completing practical legal training' (Supreme Court of Tasmania, last updated 2017: 5). South Australian applicants are required to make a disclosure where there has been a formal finding of academic dishonesty, where no formal finding has been made but a 'sanction' has been imposed, or where there is a 'pending allegation of academic dishonesty' (Law Society of South Australia, 2018: 10).

The admitting authorities in Queensland, South Australia, Northern Territory, Western Australia and NSW require applicants to consent to those authorities obtaining information from academic institutions that is relevant to the applicant such as academic misconduct or academic dishonesty. Under the Uniform Law that applies in Victoria and NSW, s 19 of the Legal Profession Uniform Rules 2015 provides that all applicants for admission must provide a student conduct report from the educational institutions where they have undertaken their academic and practical legal training courses. However the NSW admission board has varied this requirement (pursuant to Legal Profession Uniform Rules 2015 ss 27-28), requiring applicants to provide 'originals of relevant official reports' if they 'have ever been the subject of disciplinary action' in relation to their academic and/or general conduct as a law student (NSW Legal Profession Admission Board, 2018: 29). 'Disciplinary action' is defined to include 'any adverse finding' against the applicant which results in: a warning or reprimand; a reduction in marks, or the award of zero marks; failing the subject in question, or exclusion from the course; or any other penalty. There is no need to provide a student conduct report in the absence of disciplinary action. Applicants are informed that the Board conducts random audits and it will obtain student conduct reports from educational institutions in relation to a random selection of applicants.

In Victoria, however, the rule is applied and all applicants for admission are required to provide a student conduct report from each educational institution where they have undertaken their academic and practical legal training courses (Haller \& Bartlett, 2016).

Academic misconduct is clearly regarded as a 'suitability matter' in all Australian jurisdictions and acts of academic misconduct, whether past or pending determination, must be disclosed by applicants. However, the rules and processes by which admission authorities handle such disclosures do vary and applicants are dealt with differently across the jurisdictions (Haller \& Bartlett, 2016). For example, a different approach has evolved in Victoria. There applicants are advised that not all applications that contain a disclosure will be considered on the papers and matters that are the subject of disclosure, may be considered afresh at a hearing (see Haller \& Bartlett, 2016). Upon initial review of the application and disclosure, unless it is found that no further consideration is needed, the Victorian Legal Admissions Committee can: require the applicant to provide further and better particulars and/or attend an informal meeting with the Chairman and CEO; refer the application to a full meeting of the committee; refer the application to a special hearing 
held in the Supreme Court. Similarly, matters can also be heard afresh by the Supreme Court in circumstances where the admission board decides that an applicant does not meet the required standard of fitness and declines to issue a compliance certificate and/or refers the matter to the Supreme Court for consideration.

\section{The inconsistent application of plagiarism policies and procedures across legal education}

Inconsistency in the rules concerning plagiarism across Australian law schools was first comprehensively identified by Lindsay (2008) almost ten years ago where he examined 16 Australian university misconduct statutes and 22 Australian universities with respect to their construction of plagiarism (Lindsay, 2008; Lindsay, 2011). Lindsay's findings were confirmed in research by Bretag and colleagues (2012: 5) funded by the Australian Office for Learning and Teaching which covered universities more broadly. Zamitat (2012) has additionally conducted a series of plagiarism workshops around Australia with academic staff and identified variations in treatment of plagiarism across disciplines. Similarly the Australian Universities Quality Agency (AUQA) audit (2010) found inconsistency in the application of academic honesty information and testing across faculties as well as potentially inconsistent application of penalties.

Inconsistency and lack of coherent approach in addressing plagiarism in law schools has also emerged in international research (Tennant et al., 2007). For example the study by Yorke and colleagues (2009: 42) which compared plagiarism policies of 20 universities from various countries including Australia found a differing approach to 'intent' in plagiarism to be 'rife'. Similarly Bermingham and colleagues' (2010: 5-6) study which surveyed 48 UK law schools about how they define and handle suspected plagiarism found that while plagiarism was regarded as an important issue there was widespread inconsistency in approach. Most of the law schools surveyed adopted a two-tiered approach to plagiarism (minor/major) but the findings revealed significant variation across the universities in terms of terminology, definition and the procedures employed to deal with suspected incidents of plagiarism. The researchers also found that detection rates varied markedly across all institutions even though there was agreement that academic misconduct was widespread. Unsurprisingly, over $80 \%$ of the institutions studied used formal procedures to deal with major incidents of the most common types of plagiarism. However, a significant minority of institutions indicated that such acts would not attract a formal approach. The study concluded that such inconsistency within the context of an increasing quality assured system of education may lead plagiarists at some institutions to be unwitting recipients of good fortune.

The significance of the issue for the legal profession is emphasised by the growing number of Australian studies investigating plagiarism and law schools (Corbin \& Carter, 2007;

Cumming, 2007; Freckleton, 2010; James \& Mahmud, 2014; Stuhmcke, 2011; Wyburn, 2008; Wyburn, 2009). This is not surprising as a finding of plagiarism against a law student can 
have a significant impact on their future legal career: 'law students are a special case in academic integrity where a failure to disclose a breach of academic integrity can damage a graduate's reputation and prevent or delay admission into the legal profession' (James \& Mahmud, 2014: 13). Indeed the extent of the concern is reflected by the range of scholarship covering issues such as: variations in admission standards between jurisdictions (Bartlett \& Haller, 2013); whether students who plagiarise should be admitted to legal practice (Corbin \& Carter, 2008; Freckleton, 2010); the standard of university plagiarism policies such as the framing of definitions of plagiarism as an objective or a subjective test (Cumming, 2007); and the 'hands on' management of plagiarism across Australian law schools (James, 2013). This work reveals the regulatory problem that universities face where inconsistency 'may arise at any one of three points (i) formulation of university regulations and policies; (ii) their interpretation/construction both inter and intra-institutionally, and (iii) in their application by individual academic units'. ${ }^{i x}$ With estimates that $45 \%$ of law students have cheated in some way (Thomas et al., 2017: 2) the above research and this study emphasise the need for further research to address this growing phenomenon of plagiarism in legal education.

\section{Methodology and findings}

This study involves desk research and analysis of all the publicly available online academic integrity policies, procedures and related documents of 35 Australian universities which offer law as a pathway to practise. The method used in this study assesses consistency of formulation of plagiarism policies. It does not reproduce research (discussed above) which assesses the extent to which formal policies may be disregarded or discretions exercised by academics or university administrators. Appendix one provides a list of the university policies accessed and analysed for this project.

The plagiarism policies examined are institution-wide rather than faculty based, thus all disciplines and students are subject to the same university rules. Using the search terms 'plagiarism,' 'academic honesty', 'academic integrity' and 'academic misconduct' - the approach was to locate the definition of plagiarism first and then determine how alleged/proven/not proven acts of plagiarism were managed by these universities. Consistent with the research experiences of Bretag and colleagues (2011: 5) a feature of this research was the difficulty of locating and navigating the applicable policies and 'rules' in many of the institutions. The relevant rules and processes are highly nuanced and ambiguous and in many cases spread across multiple policies, guidelines, regulations and templates. For instance, at Charles Darwin University, plagiarism is defined in its Academic and Scientific Misconduct Policy but management is dealt with in a separate document: Breach of Academic Integrity Procedures. At Deakin University, plagiarism is defined in the Plagiarism and Collusion in Assessment Procedure while management is dealt with in the Student Academic Misconduct Procedure. In common with all universities studied, Deakin 
has also produced resources, the Deakin Guide to Referencing ${ }^{x}$ that provides all students (not just law students) with information about academic integrity.

This study was restricted to publicly available documents on university websites. Thus the analysis does not take account of further information that might be available to students and/or academics through sites with restricted access. For example, the University of Melbourne provides staff with a link to further guidelines in relation to the application of the plagiarism rules but access to these guidelines requires a university login.

Analysis of these publicly available documents focused on the following themes:

- Elements of the definition of plagiarism;

- The uniformity or otherwise of the definitions adopted;

- The role of student 'intent' in both defining and managing acts of plagiarism;

- Processes to investigate and penalise acts of plagiarism; and

- Recording breaches of the rules.

It became clear from the desk research that severity and intent are traditionally used by universities (informally and formally) to ascribe penalty. For example, if plagiarism occurs in the first semester and first year of a law student's degree - even if severe - a degree of unintentionality may be attributed to the act and descriptors such as 'accident' or 'first time offence' used with proportionately lighter penalties imposed than if the act had occurred later in the degree. Such timing within degree progression may also be treated differently by the admission boards (see re AJG [2004] QCA 88). This finding became a focus of further thematic research especially given the inconsistency of university approaches that became apparent. Yorke and colleagues (2009: 42) investigated the policies of 20 universities from a range of countries - Australia (9), US (6), Asia (3) and the UK (2) - in order to compare the role of 'intent' in determining whether plagiarism has occurred. That study found very little consistency in the approaches of universities studied. Intent was relevant to the determination of penalty $(n=12)$ in just over $50 \%$ of policies, but not in the remaining policies. Of those institutions that did incorporate intent only about one third attempted to define the concept $(n=4)$ though there was very little guidance provided to assist decision makers to make a determination. Yorke and colleagues (2009: 43) also found a wide variation in institutional penalties following a finding of plagiarism. Penalties ranged from educative measures to punitive disciplinary actions 'depending on the severity of the plagiarism and the decision rubric in use'. Overall they found that there is 'no common standard for how intent and plagiarism interrelate...given the implications of differential approaches and ethical considerations in terms of human rights there is a persuasive argument here for consistency in this respect' (44). 
The present study evolved to adopt a broad conceptualisation of intent that encompasses deliberation, motivation and knowledge. During the course of the analysis further themes emerged:

- Distinction of poor academic practice or similar conduct that might otherwise amount to plagiarism;

- Layers/levels of decision-making;

- Decision-makers' discretion;

- Variables and guidelines to determine penalty.

One objective was to determine whether plagiarism was confined to conduct driven by a 'dishonest' intent or whether it extended to 'non-dishonest' - 'unintentional' or 'accidental'acts that might otherwise amount to plagiarism. This issue was investigated by analysing the definitions of plagiarism for words or phrases reflecting our broad notion of intent. In the case of dishonest intent such words could include: 'dishonest', 'cheating', 'deceptive', 'intentional', 'knowingly', 'deliberately', 'wilful', and 'premeditated'. In the case of nondishonest intent such words and phrases could include: 'innocently', 'unintentional', 'accidental', 'careless,' 'negligent', 'inadvertent', 'uninformed', and 'lack of knowledge'. This study found a significant divergence in approach across the university policies, which confirms that the 2009 LACC concern with divergence in law school plagiarism policy remains a live issue. It is also clear that such divergence in approach is due to an absence of shared regulatory definitions of plagiarism. While there are common elements across the definitions - student use of work and/or ideas of another; in a manner that suggests that work/ideas are the student's own; and without appropriate acknowledgement of that other person (according to academic or disciplinary practice) - there is no uniform definition of plagiarism across our sample. ${ }^{x i}$ Plagiarism is instead a concept constructed according to policy and perhaps academic traditions of the individual institutions rather than based on coherent and consistent external standards. This represents a clear regulatory gap.

Further while most policies examined provided examples of conduct to supplement the definition of plagiarism ( $n=24)$ many of these examples, were worded differently although covering similar ground: for example, summarising and paraphrasing another's work; copying words verbatim; using ideas and/or structures without adequate referencing; copying and submitting the work of another student; and submitting work for assessment that has already been assessed. There is also an absence of uniformity as to terminology and examples are used which are open ended and imprecise. Each definition of plagiarism was analysed to determine whether student 'intent' was a necessary element. In the vast majority of cases ( $n=29$ ) student intent - that is to knowingly, deliberately, intentionally plagiarise and/or act with an intent to deceive - was not an element of the definition. The university policies in these cases were either silent with regard to intent or the definition expressly included both intentional and unintentional conduct. Though the terminology varied, the definitions of plagiarism focused on the conduct and/or work produced, not the 
intention, motivation, knowledge, or otherwise of the student involved. An example of a definition silent with regard to intent is clause 43 of the University of Melbourne's Academic Board Regulation: 'for the purposes of this regulation, a person engages in plagiarism if he or she uses another person's work as though it is his or her own work'. A definition that includes both intentional and unintentional conduct is section 2.4 of Griffith's Institutional Framework for Promoting Academic Integrity among students: plagiarism 'occurs when the work of another is represented, intentionally or unintentionally, as one's original work, without appropriate acknowledgement of the author of the source'.

Four policies require an element of dishonest intent. The Australian Catholic University's Academic Honesty policy provides that 'plagiarism is a form of academic dishonesty' and academic dishonesty is defined as 'student behaviour which does, and is intended to, provide a misleading or deceptive basis for...assessment...to which the student is not entitled'. Similarly the University of Tasmania's Plagiarism and academic integrity policy characterises plagiarism as a 'form of cheating' and defines plagiarism in line with the Dictionary of the English Language: 'the stealing or passing off as one's own (the idea or words of another)...without crediting the source'.

The policies of the University of South Queensland (USQ) and the University of Technology Sydney (UTS) also incorporate an element of dishonest intent. According to the UTS Student Rules plagiarism is: 'taking and using someone else's ideas or manner of expressing them and passing them off as his or her own by failing to give appropriate acknowledgement of the source to seek or gain an advantage by unfair means'. At USQ 'plagiarism is the action or attempt to take and use or present another person's thoughts, writing, ideas or work as their own to gain or produce unfair advantage'. The USQ policy further notes that 'A common example of plagiarism is knowingly using the whole or part of another work without citation'.

The remaining two university policies have more than one definition of plagiarism and dishonest intent is the key element of distinction. The University of Canberra (Student Conduct) Rules 2015 distinguish between 'plagiarism' (a form of academic misconduct) and 'significant plagiarism' (a form of serious academic misconduct). Clause 4 defines plagiarism as 'using the words or ideas of others and passing them off as your own in any assessment'; 'significant plagiarism' includes '(a) using the words or ideas of others in whole or significant part and passing them off as your own in any assessment...;€ committing plagiarism for a second or subsequent time. Plagiarism is defined in clause 8(2) of the University of Sydney's Academic Honesty in Coursework Policy 2015 as 'presenting another person's work as one's own work by presenting, copying or reproducing it without appropriate acknowledgment of the source... regardless of the author's intentions'. 'Dishonest plagiarism' is a form of academic dishonesty under the policy and defined as: 
Knowingly presenting another person's ideas, findings or work as one's own by copying or reproducing them without due acknowledgement of the source, with intent to deceive the examiner into believing that the content is original to the student.

Five universities add a further layer of complexity to their definitions of plagiarism by drawing a distinction between acts of plagiarism and conduct that can be broadly characterised as 'poor academic practice'. For instance, the policies of CQU and Victoria University distinguish poor referencing from plagiarism. According to the CQU Academic Misconduct Procedure: 'Poor or inadequate referencing is not plagiarism, though it still fails to meet the requirements for good academic practice'. Similarly under Victoria University's Academic Integrity and Preventing Plagiarism Policy 'incomplete attempts to acknowledge the words, works or ideas of someone else, as for example when a student makes a genuine attempt to reference their work, but has inadequate referencing skills' is not plagiarism.

The relevant policies from Monash University, Bond University and the Australian National University distinguish otherwise plagiaristic acts on the basis of intent. For conduct that is not intentional or reckless, Monash has created an offence of academic error of failing to reference a source correctly, and at Bond, instances of plagiarism resulting from 'inexperience or lack of knowledge' are defined as 'poor scholarship'. Clause 9 of the ANU Academic Misconduct Rule 15, distinguishes academic misconduct (of which plagiarism is a form) from poor academic practice.

Consistent with previous research (Lindsay, 2008 and 2011), this study has found that there continues to be no uniform, coherent and consistent definition of plagiarism across Australian universities. Moreover, although a majority of policies define plagiarism in a manner that does not require student intent, 15 of 35 policies analysed either require intent or use intent as a basis upon which to distinguish otherwise plagiaristic conduct.

Further inconsistency arises in the management of reports of plagiarism (allegations and proven breaches). Such management has several components: identity and responsibilities of decision-makers at various stages; fact finding; assessment of the seriousness of the conduct; determination of outcomes and imposition of penalties; hearings, procedural fairness and appeal processes; and reporting and recording unproven and proven breaches. Because the seriousness of the allegations has implications for adjudication and outcomes, this section focuses on the variations between university approaches to the assessment of seriousness of misconduct.

Most of the policies examined establish tiers or levels of plagiaristic conduct and those that do not, nonetheless set out a range of penalties (from educative interventions to significant punitive penalties) thereby indicating degrees of seriousness. These degrees of seriousness correlate with the nature of the act - such as intent.

There is a marked variation in policy approaches when it comes to differentiating between serious and less serious acts of plagiarism. The vast majority of policies $(n=28)$ establish a 
'hierarchy' of acts of plagiarism ranging from the relatively minor to the more serious though there are no uniform criteria to distinguish the levels of seriousness across the sample. Some policies favour various levels or tiers - such as low/medium/ high; moderate, significant and major; minor/more significant; one/two/three - others employed distinctions based on different types of plagiarism such as intentional/unintentional. For example, the University of New South Wales in its Managing Plagiarism for Students Enrolled in Coursework Programs - Procedure establishes three levels of breaches: level 1 plagiarism - minor plagiarism where inexperience is a mitigating factor; level 2 plagiarism significant plagiarism; and level 3 plagiarism - significant plagiarism and serious student misconduct. At Griffith, the Student Academic Misconduct policy and Institutional Framework for Promoting Academic Integrity among students distinguishes between two tiers of academic misconduct (plagiarism is a form of academic misconduct). There are different decision-makers for each tier and different penalties - the outcomes for tier 1 breaches are educational whereas a tier 2 breach attracts educational outcomes and penalties.

Criteria provided in policies to distinguish between the various levels or types of breaches vary markedly with regard to terminology, content and extent. The following criteria are used in the policies to establish seriousness:

- prior academic experience/stage and level of studies $(n=18)$;

- prior acts of plagiarism ( $n=15)$;

- extent of the plagiarised work $(n=13)$;

- intent, misunderstanding/careless/dishonest/deliberate/planned ( $n=8)$;

- cultural proficiency/cultural factors $(n=8)$; and

- the nature of the plagiarism/magnitude/blatancy of conduct $(n=5)$.

Criteria that are unique or occur less frequently include: capacity to adversely impact on peers or university $(n=1)$; confusion among students enrolled in a subject about the assessment (for example, regarding acceptable levels of cooperation) $(n=1)$; consequences of penalty for the student $(n=3)$; academic conventions in the particular discipline $(n=3)$; suborning/organising others $(n=1)$; penalties imposed in previous similar cases to ensure consistency $(n=1)$; signed plagiarism declarations on assessment cover sheets $(n=1)$; and the weighting of the relevant assessment item $(n=2)$.

Interestingly, few policies ( $n=5$ ) include extenuating, mitigating or otherwise 'special' circumstances as relevant to decision-making and only two establish remorse as a relevant factor to be considered. For instance, in guidelines that distinguish between academic misconduct and poor academic practice, decision-makers at the Australian National University are provided with examples of 'mitigating circumstances' including 'The student 
is at an early stage of an undergraduate program of study, and was not aware, through no fault of their own, that their actions constituted a breach of academic integrity'.

This study found that a high proportion of policies $(n=25)$, though not differentiating 'poor academic conduct' from the definition of plagiarism at the outset, nonetheless distinguish conduct such as poor scholarship, inadvertent or incorrect academic practice, arising in circumstances of 'genuine' misunderstanding of academic misconduct processes and/or inexperience otherwise applicable to plagiarism. In these cases, the policies provide for educative responses rather than penalties. For example, at RMIT under the Identification and Management of Plagiarism in Coursework Programs Instruction, 'poor referencing' is treated as an 'assessment matter' rather than academic misconduct; the penalties that can be imposed are reduction of overall mark/grade and/or resubmission. A 'level 1 ' act of plagiarism at UNSW is defined as 'minor plagiarism where inexperience is a mitigating factor'. If established, a level one breach is managed at the school level rather than according to University process under the Student Misconduct Procedure.

There is also considerable variation as to the nature and extent of guidance provided to assist decision-makers evaluate the alleged plagiaristic conduct. At one end of the spectrum are policies that provide almost no guidance for decision-makers and at the other end are policies that include comprehensive guidelines. Of course, as noted on several occasions the following observations are limited to the publicly accessible documents - and may therefore be augmented by future research with access to restricted staff and university materials.

Griffith University's Institutional Framework for Promoting Academic Integrity provides detailed guidance for decision-makers. A component of its strategy is identified as a two tier response where Tier I requires an educational or developmental response and Tier 2 requires Penalties. In order to evaluate the seriousness of the conduct and determine whether it is a tier one or tier two breach, the policy provides an 'Academic Misconduct Seriousness' matrix. The matrix is detailed and makes clear that the decision maker's judgment is an overall qualitative assessment based on five stipulated criteria - type of misconduct, extent of misconduct, experience of student, intent of student, and the impact of the misconduct. To further assist the decision maker, the matrix also provides examples of student conduct related to each criterion spread across three levels of seriousness.

UNSW also provides extensive support for decision-makers in a table of examples of the different types and levels of plagiarism together with related educative action and penalties in its Managing Plagiarism for Coursework Students Policy. For instance, an example of level 2 plagiarism ('significant plagiarism involving student misconduct') is:

A group of students worked together on an assignment after they had been told it was not allowed and some parts of the answers were identical. 
The suggested educative actions for this conduct are: School educative intervention on appropriate writing skills and academic integrity; and/or education intervention through Learning Centre Workshops. Possible penalties for this conduct are: reduction in marks by stated amount; student repeats and resubmits work for a maximum result of $50 \%$; resubmission of corrected work for a capped mark for entire course; $0 \%$ for the work; or $0 \%$ for the course.

On the other hand, the combined effect of the publicly available relevant policies of Deakin University exemplifies an approach that provides few criteria and little guidance for decision-makers. ${ }^{\text {xii }}$ Plagiarism there is a form of academic misconduct and defined in the Plagiarism and Collusion Procedure as: 'using other people's words, ideas, research findings or information without acknowledgment, that is, without indicating the source'. Under Regulation 4.1(2) - Academic Misconduct a staff member 'who has reasonable grounds to believe that an act of Academic Misconduct has been committed by a student must promptly report the matter to the Chair of the relevant Faculty Committee'. The Student Academic Misconduct Procedure policy requires the chair of that committee to determine whether the allegation of has 'merit' and allegations without merit may be dismissed. The circumstances in which an allegation may be found to lack merit include where:

a) in the opinion of the Chair...the allegation is frivolous, vexatious, misconceived, lacks substance, or is otherwise an abuse of the processes of the university;

b) the allegation is made without there being existing reasonable grounds for belief that there has been an act of Academic Misconduct.

In the event that an act of plagiarism is found to have occurred, there appears to be no framework (at least in terms of the publicly available documents) within which to determine the seriousness of the conduct to guide the decision-maker. The Student Academic Misconduct Procedure sets out the penalties for student academic misconduct in Schedule A. Those penalties range from the allocation of a zero mark for the assignment to a recommendation to the Vice-Chancellor that the degree not be awarded. However, an analysis of publicly available policies reveals a lack of guidance provided to assist decisionmakers determine the appropriate penalty in the circumstances.

Despite concerns revealed by previous research (Lindsay, 2008; Lindsay, 2011; Bretag et al., 2011) and investigations by professional bodies (LACC, 2009; AUQA, 2010), this study confirms the ongoing absence of a coherent and consistent definition of plagiarism across Australian law schools. Furthermore, this study demonstrates the significant variations between university policies in the manner in which plagiarism is determined and managed. The policies analysed disclose wide variation in how the seriousness of the act of plagiarism is evaluated and the penalties that might be imposed. Of particular note are the marked differences in criteria applied to characterise the conduct, the wide discretion available in applying that criteria, and the guidance provided for decision-makers. Although this study is confined to the words of the policies, given this lack of clarity it is not surprising that 
previous research discussed above has found inconsistent practices in managing plagiarism within individual institutions (AUQA, 2010; Bermingham et al., 2012; Yorke et al., 2009; Zamitat, 2012).

As discussed in part one, a finding (and even an unfounded allegation) of plagiarism for law students is significant for their future in legal practice (Thomas et al., 2017). Such a finding can suggest that the applicant is not a 'fit and proper' person to gain entry to the legal profession. The inability of law schools to provide a coherent and consistent definition of plagiarism and a uniform approach to the management of plagiarism, leaves a regulatory gap which is of concern to the legal profession. As the preceding analysis evidences, Australian law schools, even those in the same jurisdiction, have varying rules as to the determination and consequences for plagiarism. Thus the same act of plagiarism may be characterised differently at different institutions thus providing an unequal playing field before any application to the legal professional admission bodies. Admission authorities' tasks of reviewing each application for admission are made more complex because the information obtained from universities for each applicant relating to academic honesty will necessarily differ widely. This study indicates that in order to fully understand the nature and gravity of the academic conduct, the admission authorities will be required to examine the relevant university policies. The next part turns to the implications of these findings for admission board policies and practices.

\section{Admission to practice and inconsistent approaches to plagiarism across Australian universities}

As discussed in Part one, applicants are required to make full and frank disclosure of past acts or pending allegations of plagiarism in their application for admission. In assessing an applicant's disclosure and overall fitness to practise the admission board will be guided by the following principles: the onus is on the applicant to establish that they are a fit and proper person; past conduct is relevant but not decisive because the issue is whether an applicant is currently a fit and proper person; high standards are applied in assessing the candour of disclosures; and an applicant's 'present understanding and estimation of [the disclosed] conduct' is highly relevant (LACC, no date: 2). Admission boards will necessarily deal with multiple applications from numerous universities both within and outside their own jurisdiction. As seen in part two this assessment is problematized by the lack of a uniform and coherent approach to plagiarism across law schools. The policies and procedures dealing with plagiarism allow decision-makers a high degree of discretion and in many cases, provide little or no guidance as to the exercise of this discretion.

Although there is little information available in relation to the decision-making processes employed across the jurisdictions, it seems logical that in order to evaluate the applicant's 
candour and insight, the board must first determine the nature and seriousness of the plagiarism disclosed. This was the approach taken by the Northern Territory Supreme Court In the matter of the application of Joy Onyeledo [2015] NTSC 60. The basis for this determination at first instance (and perhaps the only basis for decision-making by the board in some jurisdictions) is documentation submitted by the applicant and the university including: the applicant's narrative; the assessment task that is the subject of the disclosure; student conduct report from the university; and any relevant university policies. Some jurisdictions do require the provision of more information. For example, in Victoria, applicants are also required to 'mark-up' the assessment task to indicate the offending sections; this mark-up is colour coded in order to distinguish different types of plagiarism such as cut-and-paste or poor paraphrasing (Haller \& Bartlett, 2016).

The absence of an unambiguous, coherent and consistent approach to the construction and handling of plagiarism at the university level thus presents significant difficulties for admission boards in evaluating the plagiaristic conduct. The applicant's narrative and the university documentation will most likely use the terminology and classification of plagiarism that is applicable to the relevant university. In the absence of guidance to assess the nature and seriousness of the conduct, the admitting authority may need to take additional care to comprehend and evaluate the academic misconduct.

The complexity of varied university approaches to plagiarism no doubt renders the task of the admission board more complex. While the determination of an applicant's standing as a 'fit and proper person' is an individual decision in each case, in order to assess one particular act as serious, there has to be an understanding of what might be less serious conduct. This study shows that the lack of a coherent, uniform approach at the university level means that students who have committed acts of plagiarism, that might otherwise be similar on the facts, are subject to a different assessment processes, different findings and different outcomes in different universities (and perhaps even in the same university). Not all academic misconduct is labelled plagiarism at each law school. For example, work that does not adequately and properly reference sources may be variously categorised as: failing to meet the requirements for good academic practice and is not plagiarism (CQU); poor referencing and is not plagiarism (RMIT); level 1 plagiarism (UNSW); minor plagiarism (QUT). If the conduct does amount to plagiarism, the different standards employed to assess the seriousness of the conduct means that it will be difficult for the admitting authorities to compare the acts of plagiarism disclosed.

There is however the possibility that admission boards may provide the uniformity or fairness in approach missing from the university assessment of plagiarism. Admission boards do have wide discretion and adopt a case-by-case approach in evaluating the conduct that is the subject of disclosure, and the applicant's candour and insight into their actions (Haller \& Bartlett, 2016). Unfortunately, there is very little publicly available information in relation to how the boards exercise their discretion in this area. Haller and Bartlett's (2016) work 
sheds some light on decision-maker's practices in NSW and Victoria, particularly the differences in processes employed to consider disclosures of academic misconduct. This is an area that requires further research.

\section{Conclusion}

There is a symbiotic relationship between the legal profession and the tertiary education sector. The law degree itself is symbolic of this close relationship. Standards of the legal profession are reflected in the legal qualifications obtained by law students who wish to practice law. For example, certain subjects are prescribed by the profession as necessary for legal practice and law degree requirements - such as duration of study and content of subject matter.

The clarity of such professional requirements for legal practice become increasingly opaque with respect to plagiarism and entry to the profession. As discussed in this article, publicly available policies reflect a reality where university decision-makers retain broad discretion with respect to characterising, actively investigating, and determining the seriousness of alleged plagiarist conduct. The highly discretionary and uneven nature of university decision-making is a well-documented and contentious issue in the field particularly because the outcomes for students will be in large part a function of the perceived 'seriousness' of the conduct.

Reform is required. This has been called for since 2009. In its recent report on Student Academic Integrity and Allegations of Contract Cheating by University Students, the Tertiary Education Quality Standards Agency (TEQSA) (2015) which is responsible for the registration of higher education providers as well as accreditation of their courses noted a number of standards relevant to academic integrity and student misconduct, including preventing, detecting and addressing cheating and plagiarism (see 4.3 of the Provider Registration Standards). Reform to ensure university standards needs to focus on establishing clear standards of conduct for students and staff (see Gullifer \& Tyson, 2014), promoting consistent decision-making and providing a degree of parity in the management of students found to have plagiarised. This in turn will facilitate admission boards who will benefit from well-articulated and consistent plagiarism policies and procedures.

It is the admission boards that will increasingly grapple with the growth in law student plagiarism and the needs of the legal profession. The reality is that admission boards are required to apply principles that the profession champions. Further research is required into the capacity and desirability for admission boards to be the new 'regulator' and provide the 'level playing field' for law students who have fallen foul of widely varying university plagiarism rules. This may assist both the admission boards and enhance the reputation and integrity of the legal profession. 


\section{References}

Australian Universities Quality Agency (2010) Report of an audit of La Trobe University (Melbourne, Australian Universities Quality Agency).

Awdry, R. \& Sarre, R. (2013) An investigation into plagiarism motivations and prevention techniques: Can they be appropriately aligned?, International Journal for Educational Integrity, 9(2), pp. 35-49.

Bartlett, F. \& Haller, L. (2013) Disclosing Lawyers: Questioning Law and Process in the Admission of Australian Lawyers, Federal Law Review, 41(2), pp. 227-263.

Batane, T. (2010) Turning to Turnitin to fight plagiarism among university students, Educational Technology \& Society 13(2), pp. 1-12.

Bermingham, V., Watson, S., \& Jones, M. (2010) Plagiarism in UK Law Schools: Is there a Postcode Lottery?, Assessment \& Evaluation in Higher Education, 35(1), pp. 1-14.

Bretag, T., Mahmud, S., Wallace, M., Walker, R., James, C., Green, M., East, J., McGowan, U. \& Partridge, L. (2011) Core elements of exemplary academic integrity policy in Australian higher education, International Journal for Educational Integrity, 7(2), pp. 3-12.

Bretag, T. (2013) Challenges in addressing plagiarism in education, PLoS Medicine, 10(12), pp. 1-4.

Bretag, T., Mahmud, S., Wallace, M., Walker, R., McGowan, U., East, J., Green, M., Partridge L., and James, C. (2014) 'Teach us How to do it Properly!' An Australian Academic Integrity Student Survey', Studies in Higher Education 39(7), pp. 1150-69.

Corbin, L. \& Carter, J. (2007) Is Plagiarism Indicative of Prospective Legal Practice?, Legal Education Review, 17(1), pp. 53-66.

Cumming, J. (2007) Where Courts and Academe Converge: Findings of Fact or Academic Judgment, Australian \& New Zealand Journal of Law \& Education, 12(1), pp. 97-108.

De Jager, K. \& Brown, C. (2010) The tangled web: investigating academics' views of plagiarism at the University of Cape Town, Studies in Higher Education, 35(5), pp. 513-528.

Devlin, M. (2006) Policy, preparation, and prevention: Proactive minimization of student plagiarism, Journal of Higher Education Policy and Management, 28(1), pp. 45-58.

Evans, M. \& Levine, P. (2016) 'We need to talk about your assignment': The requirements of Procedural Fairness when Academic Misconduct is First Suspected, Monash University Law Review, 42(2), pp. 339-359. 
Freckleton, I. (2010) Editorial: Plagiarism in Law and Medicine: Challenges for Scholarship, Academia, Publishers and Regulators, Journal of Law and Medicine, 17(5), pp. 645-659.

Gullifer, J. \& Tyson, G. (2014) Who Has Read the Policy on Plagiarism? Unpacking students' understanding of plagiarism, Studies in Higher Education, 39(7), pp. 1202-1218.

Haller, L. \& Bartlett, F. (2016) Views from the Inside: A Comparison of Admission Procedures in New South Wales and Victoria Before and After the Uniform Law, Monash University Law Review, 42(1), pp. 109-137.

Hansen, RF. \& Anderson, A. (2015) Law Student Plagiarism: Contemporary Challenges and Responses, Journal of Legal Education 64(3), pp. 416-427.

Hughes, J. \& McCabe, D. (2006) Understanding Academic Misconduct, Canadian Journal of Higher Education 36(1), pp. 49-62.

James, C. \& Mahmud, S. (2014) Promoting academic integrity in legal education: 'Unanswered questions' on disclosure, International Journal for Educational Integrity, 10(2), pp. 3-16.

James, C. (2013) Copy and be Damned: The Anxieties of Academic Integrity, Paper presented at The 2013 National Wellness for Law Forum, Melbourne, 21-22 February.

James, C. (2016) Academic Integrity in Legal Education, in: T. Bretag (Ed) Handbook of Academic Integrity (London, Springer), pp. 695-711.

Kaposi, D. \& Dell, P. (2012) Discourses of Plagiarism: Moralist, Proceduralist, Developmental and Inter-Textual Approaches, British Journal of Sociology of Sociology of Education, 33(6) pp. 813-830.

King, C.G., Guyette, R.W. \& Piotrowski, C. (2009) Online exams and cheating: An empirical analysis of business students' views, The Journal of Educators Online, 6(1), pp.1-11.

Law Admissions Consultative Committee, Law Council of Australia (2009) Law Admissions Consultative Committee Uniform Admission Arrangements.. Available at: https://www.lawcouncil.asn.au/resources/law-admissions-consultativecommittee/discussion-papers, accessed 27 January 2017.

Law Admissions Consultative Committee, Law Council of Australia (2011) Submission to Standing Committee of Attorneys-General on National Legal Profession Reform. Available at: https://www.lawcouncil.asn.au/resources/law-admissions-consultativecommittee/discussion-papers, accessed 27 January 2017.

Law Admissions Consultative Committee, Law Council of Australia (no date) Disclosure Guidelines for Applicants for Admission to the Legal Profession. Available at: 
https://www.lawcouncil.asn.au/files/web-

pdf/LACC\%20docs/211114458 27 LACC\%20Disclosure\%20Guidelines.pdf, accessed 3 May 2019.

Law Society of New South Wales (2016) Legal Profession Uniform Law. Available at: https://www.lawsociety.com.au/practising-law-in-NSW/rules-and-legislation/legalprofession-uniform-law , accessed 3 May 2019.

Law Society of South Australia (2018) Guide to Admission: Ethics and Practice Guides. Available

at:https://www.lawsocietysa.asn.au/pdf/Guide_to_Admission_as_at_March18.pdf , accessed 3 May 2019.

Lindsay, B. (2008) University Hearings: Student Discipline Rules and Fair Procedures, Australian Journal of Administrative Law, 15(3), pp. 146-168.

Lindsay, B. (2011) Student Plagiarism in Universities: The Scope of Disciplinary Rules and the Question of Evidentiary Standards, International Journal of Law \& Education, 16(1), pp. 27 46.

NSW Legal Profession Admission Board (2018) Guide for Applicants for Admission as a lawyer in NSW: in accordance with the Legal Profession Uniform Admission Rules 2015, NSW Legal Profession Admission Board. Available at:

http://www.Ipab.justice.nsw.gov.au/Documents/Guide\%20for\%20applicant\%20v2.3.pdf , accessed 3 May 2019.

Park, C. (2003) In Other (People's) Words: Plagiarism by University Students - literature and lessons, Assessment \& Evaluation in Higher Education, 28(5), pp. 471-488.

Park, C. (2004) Rebels Without a Clause: towards an institutional framework for dealing with plagiarism by students, Journal of Further and Higher Education, 28(3), pp. 291- 298.

Partridge, L. (2011) Core elements of exemplary academic integrity policy in Australian higher education, International Journal for Educational Integrity, 7(2), pp. 3-12.

Price, M. (2002) Beyond "Gotcha!": Situating Plagiarism in Policy and Pedagogy, College Composition and Education, 54(1), pp88-96.

Stuhmcke, A. (2011) Teaching Plagiarism: Law students really are that special, Journal of Australasian Law Teachers Association, 4(1), pp. 137-146.

Stuhmcke, A., Booth, T. \& Wangmann, J. (2016) The Illusory Dichotomy of Plagiarism, Assessment and Evaluation in Higher Education, 41(7), pp. 982-995. 
Supreme Court of Tasmania (last updated 2017) Admission to the Legal Profession in Tasmania: Advice to Applicants. Available at:

https://www.supremecourt.tas.gov.au/practice and procedure/admissions, accessed 3 May 2019.

Tennant, P., Rowell, G. \& Duggan, F. (2007) Academic misconduct benchmarking research project (Part I): The range and spread of penalties available for student plagiarism among UK higher education institutions, JSIC Plagiarism Advisory Service. Available at: https://www.plagiarism.org/assets/Tennant amber1.pdf,, accessed 3 May 2019.

Tennant, P \& Duggan, F. (2008) Academic Misconduct Benchmarking project: Part II, The Higher Education Academy: UK study, JSIC Advisory Service May 2008. Available at: https://www.plagiarism.org/assets/Tennant amber2.pdf, accessed 3 May 2019.

Tertiary Education Quality and Standards Agency (2015) Report on student academic integrity and allegations of contract cheating by university students. Available at: https://www.teqsa.gov.au/latest-news/publications/report-student-academic-integrity-andallegations-contract-cheating, accessed 3 May 2019.

Thomas, M., Cockburn, T. \& Yule, J. (2017) Permissible plagiarism? Navigating normative expectations in the pre- and post- admission landscape, International Journal of the Legal Profession, 24(3), pp. 295-317.

Victorian Legal Admissions Board (2017) Appearing Before the Board,. Available at: https://www.lawadmissions.vic.gov.au/about-us/appearing-before-the-board, accessed 3 May 2019.

Voelker, T. A., Love, L.G. \& Pentina, I. (2012) Plagiarism: What Don't They Know? Journal of Education for Business, 87(1), pp. 36-41

Witmer, H. \& Johansson, J. (2015) Disciplinary action for academic dishonesty: does the student's gender matter?, International Journal for Educational Integrity, 11(1), pp. 1-10.

Wyburn, M. (2008) Disclosure of prior student academic misconduct in admission to legal practice: Lessons for universities and the courts, Queensland University of Technology Law Journal, 8(2), pp. 314-341.

Wyburn, M. (2009) The confusion in defining plagiarism in legal education and legal practice in Australia, Journal of Commonwealth Law and Legal Education, 7(1), pp. 37-63.

Yorke, J., Lawson, K. \& McMahon, G. (2009) Can we reliably determine intent in cases of plagiarism?, International Journal for Educational Integrity, 5(2), pp. 39-46.

Zimitat, C. (2012) Plagiarism across the academic disciplines, Paper presented at HERDSA 35th Annual International Conference, Hobart, 2-5 July 2012. 


\footnotetext{
${ }^{i}$ In this article 'plagiarism policies' includes those university policies, rules, guidelines and procedures that relate to plagiarism. Such policies might also address academic misconduct and/or academic integrity generally.

ii Please contact authors for the list of the university policies examined.

iii Thank you to an anonymous reviewer for this point.

iv Of course it will also have differential impact on penalty imposed and therefore career consequences however that is not the focus of this article.

v Universities in Australia are largely responsible for maintaining their own quality and standards, see Higher Education Support Act 2003.

vi Legal Practitioners Act 1981 (SA) section 15(1)(a); Legal Profession Act 2006 (ACT) section 26(2)(b); Legal Profession Uniform Law 2014 NSW) section 17(2); Legal Profession Act (NT) section 25(2)(b); Legal Profession Act 2007 (Qld) section 35(2)(a); Legal Profession Act 2007 (Tas) section 31(6)(b); Legal Profession Uniform Law, Schedule 1, Legal Profession Uniform Law Application Act 2004 (Vic) section 15(b); Legal Profession Act 2008 (WA) section 26(1)(a)(ii).
}

viii Law Admissions Consultative Committee Uniform Admission Arrangements - July 2009 http://www.lawcouncil.asn.au/LACC/images/pdfs/UniformAdmissionArrangementssubmissiontoCOAGTaskfor ce.pdfp 10, accessed 27 January 2017.

ix Thanks to an anonymous referee for this point.

${ }^{x}$ Available at http://www.deakin.edu.au/students/study-support/referencing accessed 3 May 2019.

${ }^{x i}$ In this regard it is noteworthy that the definitions of plagiarism in the relevant plagiarism policies of CDU and Flinders are almost identical. Given the nature of plagiarism it is also noteworthy that references are included for definitions of plagiarism and/or related process in only three university policies: La Trobe, 39(f) Academic Integrity Policy, Tasmania, clause 5 Plagiarism and Academic Integrity Policy, and Griffith University's Institutional Framework for Promoting Academic Integrity Among Students. The latter policy includes an acknowledgement that it is "adapted from the Lancaster Framework with their permission".

xii Here it must be stressed that this research is confined to publicly available data. 